\title{
A high-resolution Late Glacial to Holocene record of environmental change in the Mediterranean from Lake Ohrid (Macedonia/Albania)
}

\author{
Jack H. Lacey • Alexander Francke • Melanie J. Leng • \\ Christopher H. Vane $\cdot$ Bernd Wagner
}

Received: 18 December 2013 / Accepted: 6 May 2014 / Published online: 23 May 2014

(C) Springer-Verlag Berlin Heidelberg 2014

\begin{abstract}
Lake Ohrid (Macedonia/Albania) is the oldest extant lake in Europe and exhibits an outstanding degree of endemic biodiversity. Here, we provide new high-resolution stable isotope and geochemical data from a $10 \mathrm{~m}$ core (Co1262) through the Late Glacial to Holocene and discuss past climate and lake hydrology (TIC, $\delta^{13} \mathrm{C}_{\text {calcite }}, \delta^{18} \mathrm{O}_{\text {calcite }}$ ) as well as the terrestrial and aquatic vegetation response to climate (TOC, TOC/N, $\delta^{13} \mathrm{C}_{\text {organic }}$, Rock Eval pyrolysis). The data identifies 3 main zones: (1) the Late Glacial-Holocene transition represented by low TIC and TOC contents, (2) the early to mid-Holocene characterised by high TOC and increasing TOC/N and (3) the Late Holocene-Present which shows a marked decrease in TIC and TOC. In general, an overall trend of increasing $\delta^{18} \mathrm{O}_{\text {calcite }}$ from $9 \mathrm{ka}$ to present suggests progressive aridification through the Holocene, consistent with previous records from Lake Ohrid and the wider Mediterranean region. Several proxies show
\end{abstract}

\section{J. H. Lacey $(\bowtie)$}

Department of Geology, University of Leicester,

Leicester LE1 7RH, UK

e-mail: j1237@ leicester.ac.uk

J. H. Lacey $\cdot$ M. J. Leng

NERC Isotope Geosciences Facilities, British Geological Survey, Keyworth, Nottingham NG12 5GG, UK

\section{A. Francke $\cdot$ B. Wagner \\ Institute for Geology and Mineralogy, University of Cologne, 50674 Cologne, Germany}

\section{J. Leng}

Centre for Environmental Geochemistry, School of Geography, University of Nottingham, Nottingham NG7 2RD, UK

C. H. Vane

British Geological Survey, Keyworth, Nottingham NG12 5GG, UK commensurate excursions that imply the impact of shortterm climate oscillations, such as the $8.2 \mathrm{ka}$ event and the Little Ice Age. This is the best-dated and highest resolution archive of past Late Glacial and Holocene climate from Lake Ohrid and confirms the overriding influence of the North Atlantic in the north-eastern Mediterranean. The data presented set the context for the International Continental scientific Drilling Program Scientific Collaboration On Past Speciation Conditions in Lake Ohrid project cores recovered in spring-summer 2013, potentially dating back into the Lower Pleistocene, and will act as a recent calibration to reconstruct climate and hydrology over the entire lake history.

Keywords Lake Ohrid · Mediterranean · Holocene · Stable isotopes · Geochemistry · Rock Eval · Palaeolimnology

\section{Introduction}

Understanding past variation in climate and hydrology in the Mediterranean is vital for establishing future climate scenarios and assessing the potential impact on human populations, as changes in water resources and rainfall are predicted to have important social, economic and political impacts across the region (Giannakopoulos et al. 2009; García-Ruiz et al. 2011). It has been shown that local climate and hydrological change can be defined by stable isotope data from lacustrine carbonates and organic matter $(\mathrm{OM})$ through time (i.e. Leng and Marshall 2004; Leng et al. 2013) and that a regional combination of lake isotope records can be used to assess the spatial coherency of climate change (Roberts et al. 2008). 


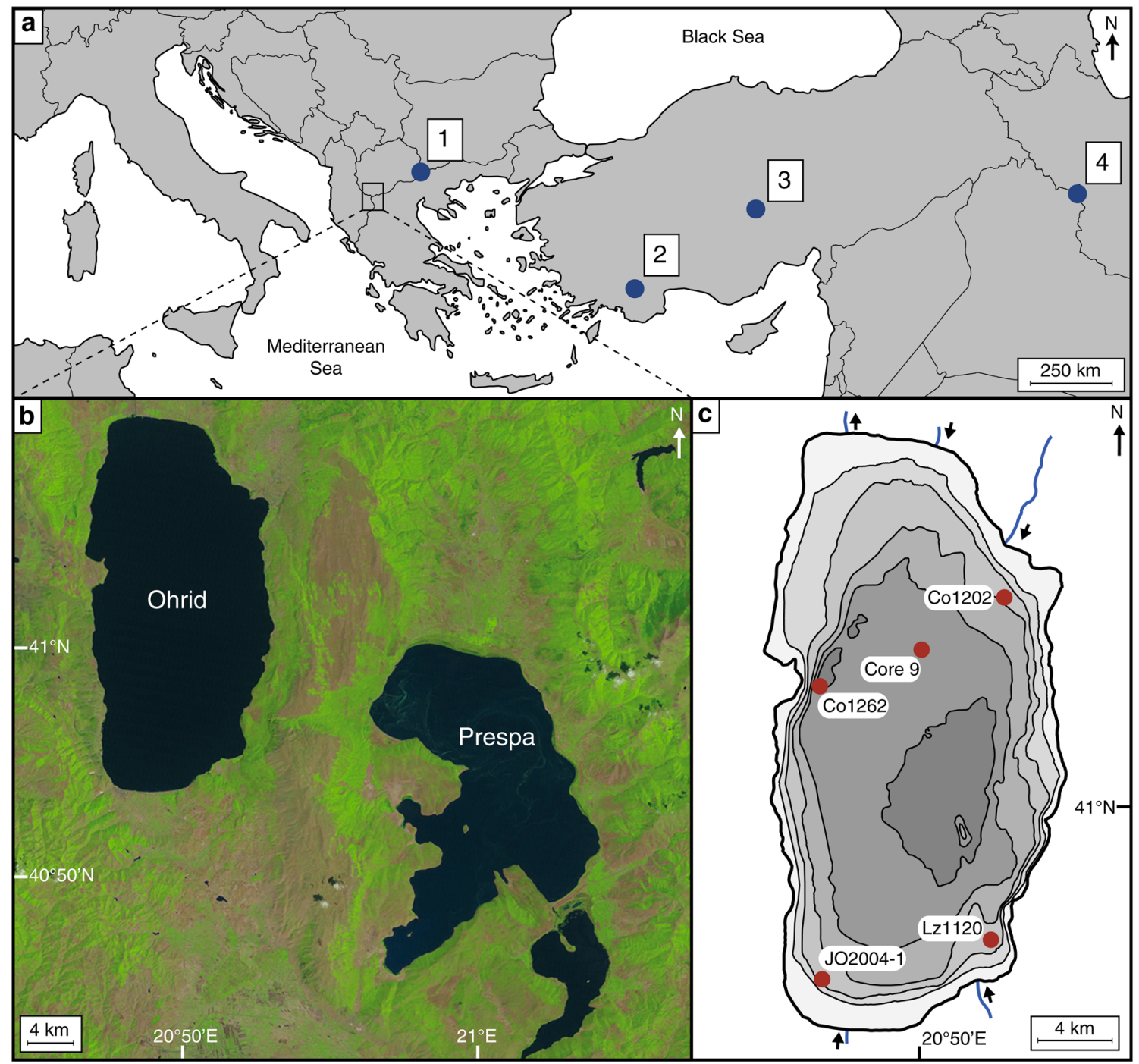

Fig. 1 a, b Map of the north-eastern Mediterranean showing the location of Lake Ohrid, Lake Prespa and other key sites mentioned in the text, including 1 Lake Dojran, 2 Lake Gölhisar, 3 Lake Eski Acigöl, 4 Lake Zeribar. c Bathymetry of Lake Ohrid (defined by $50 \mathrm{~m}$ isolines) showing river input/output and the location of coring sites

There are numerous stable isotope records from lakes in the Mediterranean (e.g. Zanchetta et al. 2012; Dean et al. 2013; Leng et al. 2013), and several sediment cores have been recovered and analysed from multiple locations within Lake Ohrid (Fig. 1; Roelofs and Kilham 1983; Belmecheri et al. 2009; Wagner et al. 2009, 2012; Vogel et al. 2010a). The records from Lake Ohrid have shown the lake to provide an archive of long-term climatic and environmental change (e.g. Vogel et al. 2010a) and, in the recent sediments, of changes in nutrient supply from anthropogenic impact (Matzinger et al. 2007). However, high-resolution data are needed to better understand rapid climatic variability and anthropogenic activity across the region
Co1202 (Vogel et al. 2010a), Core 9 (Roelofs and Kilham 1983), Co1262 (this study; Wagner et al. 2012), Lz1120 (Wagner et al. 2009), and JO2004-1 (Belmecheri et al. 2009). c Modified from Vogel et al. (2010a, Fig. 2b)

(Francke et al. 2013). Here, we present stable isotope and geochemical data from OM, including carbon isotope composition, Total Organic Carbon and Nitrogen $\left(\delta^{13} \mathrm{C}_{\text {organic }}\right.$, TOC, TOC/N), Rock Eval data including both Hydrogen Index (HI) and Oxygen Index (OI) and oxygen and carbon isotope composition of calcite $\left(\delta^{18} \mathrm{O}_{\text {calcite }}\right.$ and $\left.\delta^{13} \mathrm{C}_{\text {calcite }}\right)$ through the Late Glacial to Holocene. Using the combined dataset, an interpretation of past climate and environment is discussed and the data are compared with neighbouring lakes Prespa and Dojran, as well as other lakes across the Eastern Mediterranean. The data presented here is the bestdated and highest resolution record from Lake Ohrid for the Late Glacial and Holocene period and sets the context 
for the future work on the new International Continental scientific Drilling Program (ICDP) cores that potentially go back at least 1.2 million years (Wagner et al. 2014).

\section{General setting}

Lake Ohrid $\left(40^{\circ} 54^{\prime}-41^{\circ} 10^{\prime} \mathrm{N}, 20^{\circ} 38^{\prime}-20^{\circ} 48^{\prime} \mathrm{E}\right)$ is a transboundary lake located within the north-eastern Mediterranean, spanning the border between Macedonia and Albania to the west of the Balkan Peninsula (Fig. 1). It is situated at an altitude of $693 \mathrm{~m}$ above sea level (asl) and is bounded to the west by the Mokra Mountain Chain $(1,500 \mathrm{~m}$ asl) and to the east by the Galičica Mountain $(2,262 \mathrm{~m}$ asl $)$ and Mali Thate Mountain Chains (2,287 m asl; Albrecht and Wilke 2008). Lake Ohrid formed in an approximately N-S trending graben towards the end of the Alpine orogeny during the Pliocene (Aliaj et al. 2001), as a result of extensional tectonics that are still active today (Reicherter et al. 2011; Hoffmann et al. 2012). The lake has a maximum N-S length of $30.8 \mathrm{~km}$, a maximum E-W width of $14.8 \mathrm{~km}$ and covers an area of $358 \mathrm{~km}^{2}$ (Stankovic 1960). The basin has a bathtub-shaped morphology with a maximum water depth of $293 \mathrm{~m}$ and an estimated volume of $50.7 \mathrm{~km}^{3}$ (Fig. 1; Popovska and Bonacci 2007). In the deepest parts of the lake, sediment accumulation rates are $\approx 0.5 \mathrm{~mm} \mathrm{year}{ }^{-1}$ (Wagner et al. 2008a).

The climate in the region surrounding Lake Ohrid is controlled by both sub-Mediterranean and continental influences (Panagiotopoulos et al. 2013), owing to the lake's position in a deep valley sheltered by the surrounding mountains and its proximity to the Adriatic Sea (Vogel et al. 2010a). Average annual rainfall within the Lake Ohrid watershed is $907 \mathrm{~mm}$ and average annual air temperature is $+11.1{ }^{\circ} \mathrm{C}$, ranging from -5.7 to $+31.5{ }^{\circ} \mathrm{C}$ (Popovska and Bonacci 2007). North-south winds dominate (>75\%) and trace the Ohrid valley, with northerly winds prevailing in autumn-winter and southerly winds in spring-summer (Stankovic 1960).

The Lake Ohrid catchment covers an area of around $1,002 \mathrm{~km}^{2}$ (Popovska and Bonacci 2007), which increases to $2,600 \mathrm{~km}^{2}$ when aquifer input from neighbouring Lake Prespa is included (Matzinger et al. 2006b). Lake Prespa, situated $10 \mathrm{~km}$ to the east and $150 \mathrm{~m}$ above Lake Ohrid at $849 \mathrm{~m}$ asl (Leng et al. 2013), feeds Lake Ohrid through a network of karst aquifers which account for $55 \%$ of water input into the lake (Matzinger et al. 2006a); the remaining $45 \%$ of overall input comes from direct precipitation on the lake's surface and river inflow (Albrecht and Wilke 2008). The karst aquifer input comprises $49 \%$ sub-lacustrine karst springs and $51 \%$ surface springs (Matzinger et al. 2006a; Matter et al. 2010). The main hydrological output from Lake Ohrid is through the River Crn Drim
(66\%) to the northern shore, and the residual third is lost through evaporation and seepage (Matzinger et al. 2006b). The upper $150 \mathrm{~m}$ of the lake water is thermally stratified in summer months and mixed through winter; below $150 \mathrm{~m}$ the lake is stratified by salinity, only mixing on a sub-decadal cycle (Hadzisce 1966; Matzinger et al. 2006b). Presently, Lake Ohrid is oligotrophic with an average Secchi depth of approximately $14 \mathrm{~m}$ (Matzinger et al. 2006b).

\section{Materials and methods}

\section{Core recovery}

A ca. 10-m sediment core (Co1262) was recovered from a locality to the east of the Lini Peninsula $\left(41^{\circ} 03^{\prime} 56.9^{\prime \prime} \mathrm{N}\right.$, $020^{\circ} 40^{\prime} 21.9^{\prime \prime} \mathrm{E}$ ) in $260 \mathrm{~m}$ water depth during June 2011. The core was retrieved in $2 \mathrm{~m}$ long sections from a floating platform using a gravity corer for shallower sediments and a percussion piston corer for deeper sediments, where core recovery approached $100 \%$. The coring location was selected based on hydro-acoustic surveys conducted over the period 2004-2009, primarily to study the link between 'mass wasting' deposits (MWD) and earthquakes (Reicherter et al. 2011). Lindhorst et al. (2014) describe the hydro-acoustic surveys that record information on the sedimentary architecture and bathymetry of Lake Ohrid. These show prominent faults and half-graben structures, where successions of MWD are present (Wagner et al. 2012). Post-recovery, the core was split into roughly $1 \mathrm{~m}$ long sections and stored in darkness at $4{ }^{\circ} \mathrm{C}$. Subsequently, the core segments were opened, halved lengthwise, described macroscopically, split into $2 \mathrm{~cm}$ segments (total correlated core depth $=10.05 \mathrm{~m}$ ) and then freeze dried. The concentration of total inorganic carbon (TIC) was determined using a DIMATOC 200 (DIMATEC Co.; Wagner et al. 2012).

Geochemistry of organic matter

Core Co1262 was sampled for organic geochemistry from the surface to $119 \mathrm{~cm}$ (correlated depth) every $2 \mathrm{~cm}$, beneath which a $202 \mathrm{~cm}$ thick MWD occurs (Wagner et al. 2012). Samples were then taken at $2 \mathrm{~cm}$ intervals from 321 to $963 \mathrm{~cm}$ to a second MWD $(18 \mathrm{~cm})$; below $981 \mathrm{~cm}$ sampling continued to the base of the core at $1,005 \mathrm{~cm}$. The MWD material is homogenous with no significant changes in TIC or organic content (Wagner et al. 2012) and was not analysed as the horizons represent short-term events that can be considered instantaneous.

For the $\delta^{13} \mathrm{C}_{\text {organic }}$ of OM, TOC and N, around $500 \mathrm{mg}$ sample was added to $5 \% \mathrm{HCl}$ to remove calcite, rinsed in deionised water, dried at $40{ }^{\circ} \mathrm{C}$ and then transferred to a vial after being ground to a fine powder and homogenised. 
The samples were combusted using a Costech ECS4010 elemental analyser at approximately $1,400{ }^{\circ} \mathrm{C}$, and then analysed using a VG Optima dual inlet mass spectrometer. $\delta^{13} \mathrm{C}_{\text {organic }}$ are reported as per mil $(\% \circ)$ deviations of the ${ }^{13} \mathrm{C} /{ }^{12} \mathrm{C}$ ratio calculated to the Vienna Pee Dee Belemnite (VPDB) scale, utilising within-run laboratory and international standards. Analytical reproducibility for the withinrun standards was $<0.1 \%$ of $\delta^{13} \mathrm{C}_{\text {organic }},<0.7 \%$ for TOC and $<0.2 \%$ for $\mathrm{N}$.

For Rock Eval analysis, approximately $60 \mathrm{mg}$ of sediment was used. Each sample was heated at $25{ }^{\circ} \mathrm{C} \mathrm{min}{ }^{-1}$ in an inert atmosphere of $\mathrm{N}_{2}$ from 300 up to $650{ }^{\circ} \mathrm{C}$, after which the residual carbon was oxidised at $20{ }^{\circ} \mathrm{C} \mathrm{min}{ }^{-1}$ from 300 to $850{ }^{\circ} \mathrm{C}$. A flame ionisation detector measured the release of hydrocarbons during the two-stage pyrolysis and an infrared cell monitored $\mathrm{CO}$ and $\mathrm{CO}_{2}$ release during thermal cracking of the bound OM. The performance of the instrument was assessed against IFP 160000 and S/N1 5-081840. Rock Eval analysis gives 13 acquisition parameters which are determined by integrating the amounts of $\mathrm{OM}, \mathrm{CO}$ and $\mathrm{CO}_{2}$; including $\mathrm{S} 1$ (hydrocarbons previously generated, distilled out upon heating to $300{ }^{\circ} \mathrm{C}$ ) and S2 (hydrocarbons generated through cracking of bound $\mathrm{OM}$, upon temperature increase to $850{ }^{\circ} \mathrm{C}$ ). This paper presents the HI (S2*100/TOC) and OI (S3*100/TOC), with analytical reproducibility for the within-run standards of $\mathrm{HI} \pm 16$ and $\mathrm{OI} \pm 3$.

Stable isotope analysis of carbonates

The sediments of Co1262 were sampled for $\delta^{18} \mathrm{O}_{\text {calcite }}$ and $\delta^{13} \mathrm{C}_{\text {calcite }}$ at the same resolution as the organic samples to $729 \mathrm{~cm}$. Below $729 \mathrm{~cm}$, TIC content decreases to $<0.1 \%$ (apart from a spike at $775 \mathrm{~cm}$; Wagner et al. 2012) to $813 \mathrm{~cm}$ and sampling was thereafter carried out at $4 \mathrm{~cm}$ intervals. There are small TIC spikes $(0.2-2 \%)$ at 965-981 cm, where a MWD horizon is observed (Wagner et al. 2012). Samples from two previous Lake Ohrid cores (Co1202 and Lz1120) were analysed by XRD to determine mineralogy of the carbonate (cf. Leng et al. 2010), the TIC was confirmed to be calcite, which is in agreement with observations that have been made using SEM (Lézine et al. 2010; Matter et al. 2010).

The subsamples were processed to oxidise reactive organic material by disaggregating around $500 \mathrm{mg}$ of sample in $100 \mathrm{ml}$ of $5 \%$ sodium hypochlorite solution for $24 \mathrm{~h}$. Following this, the samples were sieved at $63 \mu \mathrm{m}$, which is usually assumed to remove any potential biogenic carbonate (Leng et al. 2013). The $<63 \mu \mathrm{m}$ fraction was rinsed three times in deionised water, dried at $40{ }^{\circ} \mathrm{C}$ and powdered. Once prepared, the subsamples were reacted overnight in a vacuum with anhydrous phosphoric acid at a constant $25^{\circ} \mathrm{C}$, to evolve the $\mathrm{CO}_{2}$ for analysis. The $\mathrm{CO}_{2}$ was
Table 1 Calibrated radiocarbon and tephra ages used in the age model for core Co1262

\begin{tabular}{lll}
\hline Core depth $(\mathrm{cm})$ & Material & Age (cal. yr BP) \\
\hline 17 & Terrestrial plant & $140 \pm 145$ \\
320 & $\begin{array}{l}\text { Somma-Vesuvius AD 472/512 } \\
\text { tephra }\end{array}$ & $1,478 / 1,438^{\mathrm{a}}$ \\
& Terrestrial plant & $2,190 \pm 140$ \\
442 & Etna FL tephra & $3,370 \pm 70^{\mathrm{b}}$ \\
517 & Terrestrial plant & $3,510 \pm 110$ \\
520 & Terrestrial plant & $3,850 \pm 130$ \\
537 & Terrestrial plant & $5,030 \pm 190$ \\
574 & Mercato tephra (glass shards) & $8,530 \pm 100^{\mathrm{c}}$ \\
709 & Fish bone & $12,400 \pm 190$ \\
754 &
\end{tabular}

The calibration of radiocarbon ages is based on Calib 6.1.1 (Stuiver and Reimer 1993) and INTCAL09 (Reimer et al. 2009) and on a $2 \sigma$ uncertainty (Wagner et al. 2012)

${ }^{\mathrm{a}}$ Vogel et al. (2010b), ${ }^{\mathrm{b}}$ Coltelli et al. (2000), ${ }^{\mathrm{c}}$ Zanchetta et al. (2011)

Table $2 R^{2}$ values for cross-plots shown in Fig. 4 calculated within Zone I $=0-2 \mathrm{ka}$, Zone II $=2-8 \mathrm{ka}$, Zone III $=8-12.3 \mathrm{ka}$ and whole core $=0-12.3 \mathrm{ka}$

\begin{tabular}{llllll}
\hline Figure 4 & Proxy & Zone I & Zone II & Zone III & Whole core \\
\hline $\mathrm{a}$ & TOC/N-HI & 0.23 & 0.84 & 0.86 & 0.64 \\
$\mathrm{~b}$ & TOC/N-OI & 0.25 & 0.72 & 0.59 & 0.51 \\
$\mathrm{c}$ & TOC/N- $\delta^{13} \mathrm{C}_{\text {organic }}$ & 0.20 & 0.63 & 0.06 & 0.17 \\
$\mathrm{~d}$ & TOC-HI & 0.70 & 0.91 & 0.92 & 0.92 \\
$\mathrm{e}$ & $\mathrm{HI}-\mathrm{OI}$ & 0.69 & 0.55 & 0.65 & 0.48 \\
$\mathrm{f}$ & $\delta^{18} \mathrm{O}_{\text {calcite }}-\delta^{13} \mathrm{C}_{\text {calcite }}$ & 0.35 & 0.00 & 0.05 & 0.02 \\
\hline
\end{tabular}

analysed using a VG Optima dual inlet mass spectrometer. The mineral-gas fractionation factor used for calcite was 1.01025 (derived from Rosenbaum and Sheppard 1986). $\delta^{18} \mathrm{O}_{\text {calcite }}$ and $\delta^{13} \mathrm{C}_{\text {calcite }}$ are reported as per mil (\%o) deviations of the isotopic ratios $\left({ }^{18} \mathrm{O} /{ }^{16} \mathrm{O}\right.$ and $\left.{ }^{13} \mathrm{C} /{ }^{12} \mathrm{C}\right)$ calculated to the Vienna Pee Dee Belemnite (VPDB) scale, utilising within-run laboratory and international standards (MCS and CCS). Analytical reproducibility for the within-run standards was $<0.1 \%$ o for $\delta^{18} \mathrm{O}_{\text {calcite }}$ and $\delta^{13} \mathrm{C}_{\text {calcite. }}$.

\section{Results}

\section{Chronology}

The age model for Co1262 is based on 6 radiocarbon ages, 3 tephras and cross-correlation with published records from Lake Ohrid and nearby Lake Prespa (Table 1; Fig. 2). Wagner et al. (2012) give an expanded discussion for each dating point and a summary of chronological control. The age-depth model (Fig. 2) for the pelagic sediments of core Co1262 was calculated with the software package CLAM 


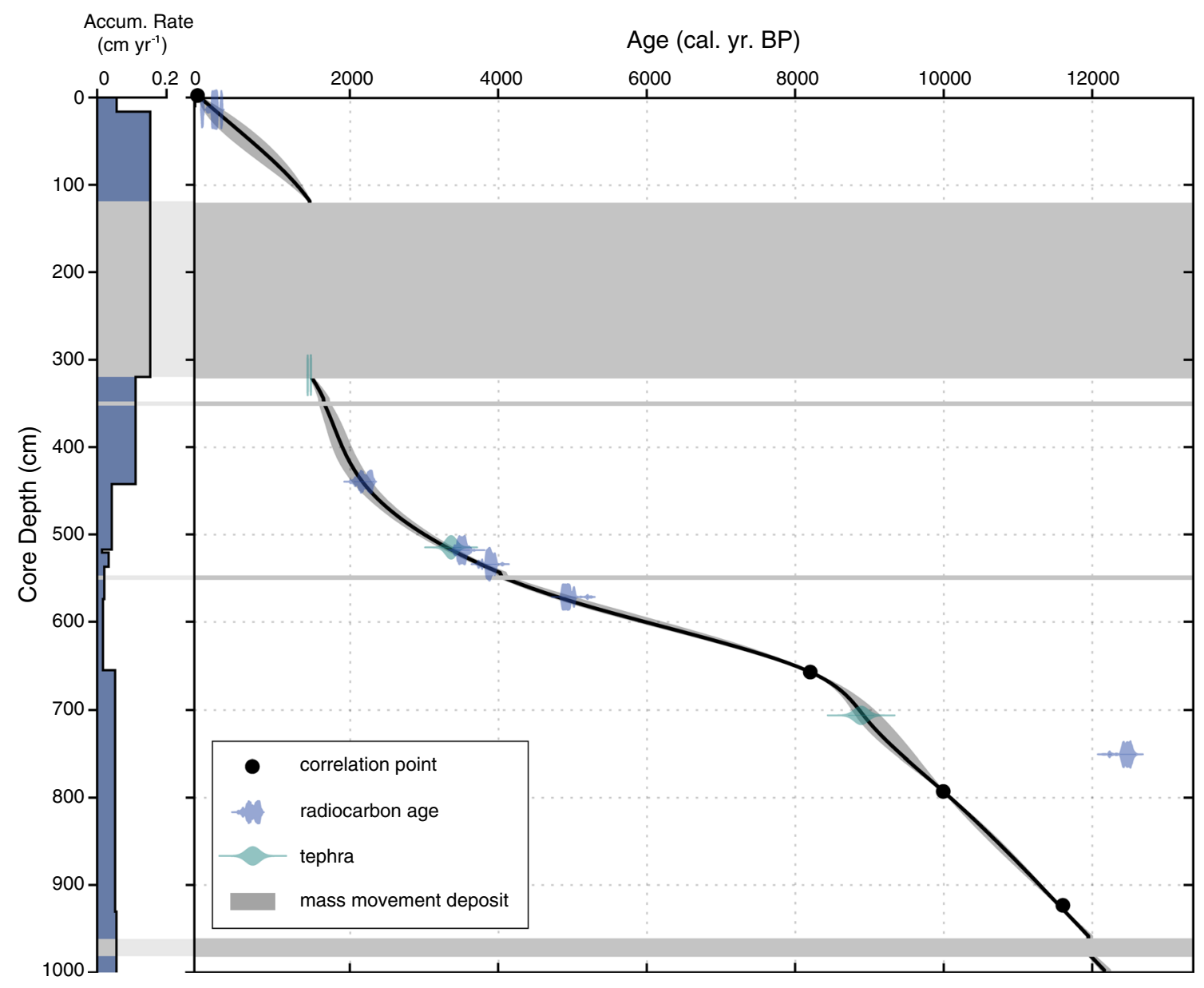

Fig. 2 Age-depth model of core Co1262 based on 3 tephra geochemical correlations, six calibrated radiocarbon ages derived from terrestrial plant and fish material and cross-correlation of physical parameters, such as TIC, with previous Lake Ohrid and Lake Prespa cores. Accumulation rate $\left(\mathrm{cm} \mathrm{year}^{-1}\right)$ was calculated between known dates using correlated core depths $(\mathrm{cm})$. Wagner et al. (2012) describes the

v.2.2 (Blaauw 2010), operating with the IntCal 13 calibration curve (Reimer et al. 2013). The age model was interpolated between the radiocarbon ages, the tephras and cross-correlation points using a smooth spline function (smoothing $=0.1$ ). MWD were not included in the calculations and subtracted from the composite profile.

Six radiocarbon ages have been obtained, 5 from terrestrial plant material and 1 using fish remains. The fish remains produce a radiocarbon date of 12,400 cal. yr. BP indicating a much older age than expected $(754 \mathrm{~cm}$ depth $=9,433 \mathrm{cal}$. yr. BP). A reservoir effect of $>1,500$ years has been documented in previous Lake Ohrid cores (Wagner et al. 2008a; Vogel et al. 2010a), however, a discrepancy of 3,000 years is most likely explained by a combined scenario of reservoir effect and re-deposition. The three tephras, distinguished in horizons marked by high levels of $\mathrm{K}$ and $\mathrm{Sr}$, have been previously well dated correlation to other Lake Ohrid and Lake Prespa cores in full. Blue radiocarbon curves represent the most probable distribution of calibrated ages. Green tephra markers display a Gaussian distribution of calibrated age error (Table 1). MWD found at 121-319, 346-350, 545-549 and 960-980 cm are shown as light grey bands

in Lake Ohrid (Table 1; Sulpizio et al. 2010; Vogel et al. 2010b). Wagner et al. (2012) describes the major element composition of the tephra and cryptotephra for Co1262.

The age model for core Co1262 shows a high sedimentation rate of $1.1 \mathrm{~mm} \mathrm{year}^{-1}$ within the upper and lower sections, reducing to $0.6 \mathrm{~mm}_{\text {year }}{ }^{-1}$ between 450 and $650 \mathrm{~cm}$, and gives a basal age of ca. $12.3 \mathrm{ka}$ (Fig. 2). The base of the core reaches back into the last glacial period, which is confirmed by the presence of coarse-grained material (thought to represent ice-rafted debris) and low TIC (Wagner et al. 2009, 2012; Vogel et al. 2010a). Due to the variable sedimentation rate (Fig. 2), the constant sample size of $2 \mathrm{~cm}$ incorporates differing amounts of climate signal providing a resolution (per centimetre) of approximately 20-40 years in the middle part of the core and a greater resolution of 10-20 years in the lower and upper parts of the core (Fig. 2). 


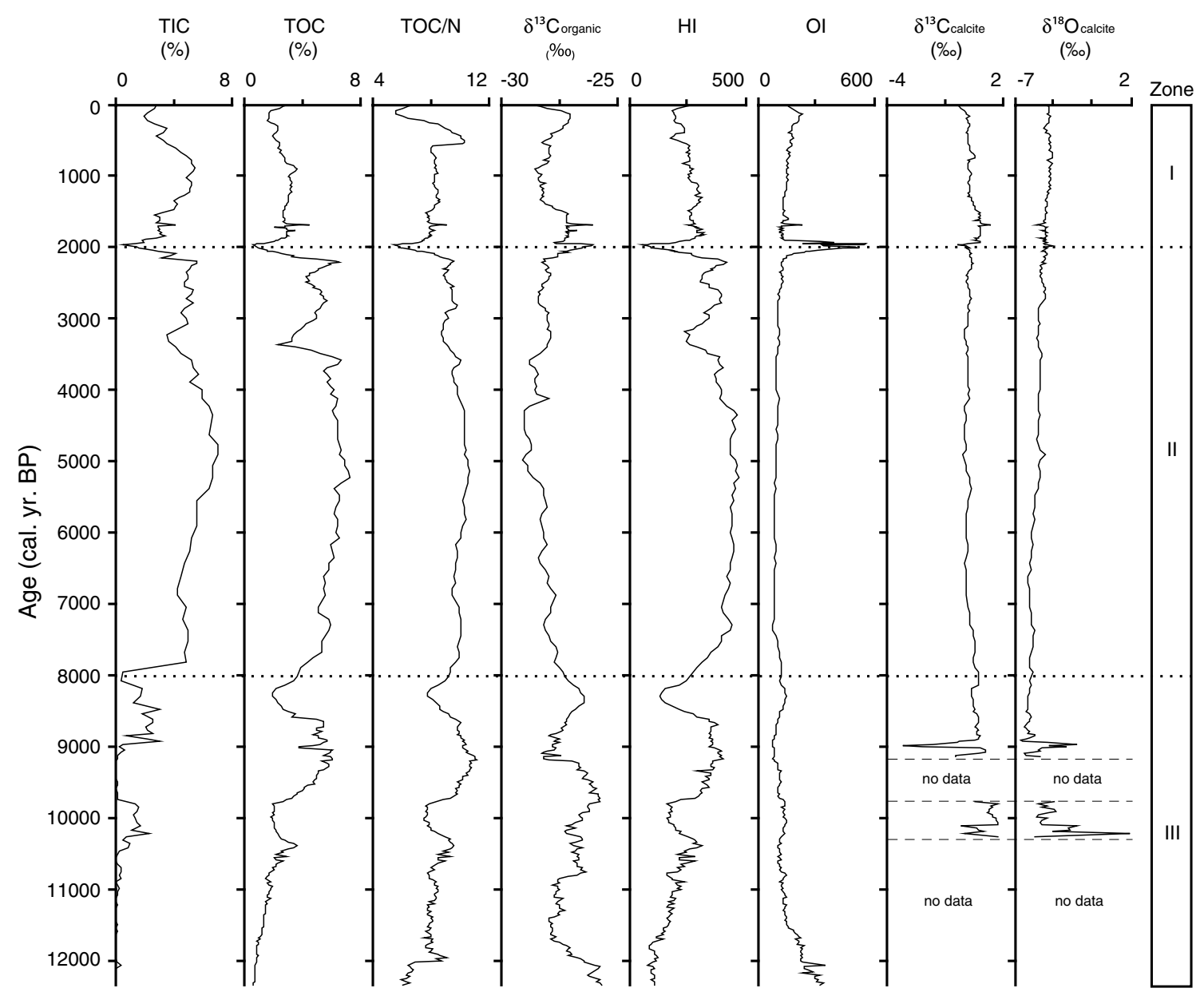

Fig. 3 Multi-proxy data from Lake Ohrid core Co1262. The data fall into 3 main zones (I, II and III; dashed lines). The chronology is based upon dates given in Table 1 and shown in the age model

Organic geochemistry and stable isotope analysis

The Lake Ohrid core Co1262 covers the last $12.3 \mathrm{ka}$, and therefore spans the transition from the Late Glacial through to the Holocene. In general, the sediments comprise greyisholive homogenous clay to silt grade mud, with minor changes in colour associated with varying TIC and TOC (Fig. 3, Wagner et al. 2012). The sediments are massive and structureless, similar to other Lake Ohrid Holocene sequences, which can be attributed to bioturbation (Wagner et al. 2009; Vogel et al. 2010a). The core features several horizons of increased grain size (sand to gravel) and decreased water content that are thought to represent MWD (Wagner et al. 2012). TOC is minimal $(<1 \%)$ in the lower part of the core. Higher TOC occurs between 8 and $3.5 \mathrm{ka}$, with a maximum of $7.3 \%$ at $5.2 \mathrm{ka}$. Thereafter, TOC decreases to around $3 \%$. Over the majority of the core TOC results are tracked by TOC/N ratios, where TOC/N ranges from 5.5 to 11.2 , excluding a rapid increase at $12 \mathrm{ka}$ and a large excursion to higher values around
(Fig. 2). $\delta^{18} \mathrm{O}_{\text {calcite }}$ and $\delta^{13} \mathrm{C}_{\text {calcite }}$ 'no data' horizons are due to low calcite content $($ TIC $<0.5 \%)$

0.5 ka. $\delta^{13} \mathrm{C}_{\text {organic }}$ averages $-27.5 \%$ over the entire record, has elevated values in the upper and lower core sections and decreases to a minimum of $-29.0 \%$ o through the central unit. $\delta^{13} \mathrm{C}_{\text {organic }}$ is generally opposed to TOC and TOC/N. HI values from Rock Eval analysis track changes in TOC/N, having lower values in the upper and lower parts of the core, reaching a maximum of 470 at $5.2 \mathrm{ka}$ and a minimum of 57 at $2.0 \mathrm{ka}$. OI broadly opposes $\mathrm{HI}$ but is by comparison relatively constant, except from a spike at $2.0 \mathrm{ka}$, commensurate with the $\mathrm{HI}$ minimum. At the base of the core, there are two zones of minimum TIC (below $10.3 \mathrm{ka}$ and between 9.8 and $9.1 \mathrm{ka}$ ) where TIC $<0.5 \%$ was difficult to analyse for stable isotopes. Maximum TIC (7.1\%) occurs at $4.9 \mathrm{ka}$, approximately at the same time as maximum TOC, and mirrors high TOC values through the section until $2 \mathrm{ka}$. From the base of the core to $8.5 \mathrm{ka}$, $\delta^{18} \mathrm{O}_{\text {calcite }}$ values are erratic but generally decrease, fluctuating between -6.5 and $+1.9 \%$, then gradually increase by $+2 \%$ o through the main body of core to the current value of $-4.5 \%$. $\delta^{13} \mathrm{C}_{\text {calcite }}$ values show a similar range, the maximum value of 

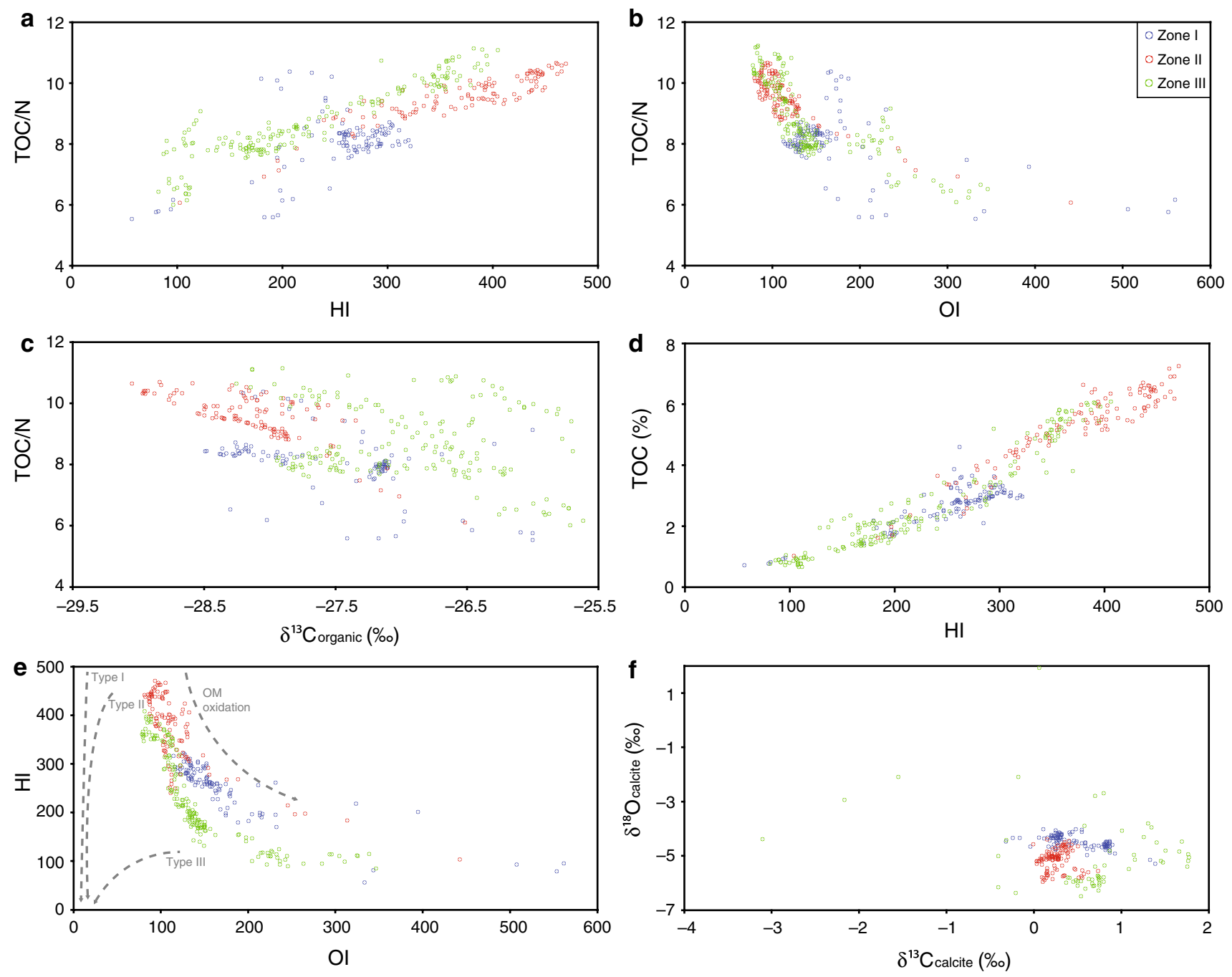

Fig. 4 Cross-plots of a TOC/N versus HI, b TOC/N versus OI, c TOC/N versus $\delta^{13} \mathrm{C}_{\text {organic }}$, $\mathbf{d}$ TOC versus $\mathrm{HI}$, e HI versus OI and $\mathbf{f}$ $\delta^{18} \mathrm{O}_{\text {calcite }}$ versus $\delta^{13} \mathrm{C}_{\text {calcite. }}$ Blue dots Zone I (0-2 ka), red dots Zone II (2-8 ka) and green dots Zone III (8-12.3 ka). $R^{2}$ values for each plot and zone are given in Table 2. e OM from Lake Ohrid on a van

$+1.8 \%$ being towards the base of the core and the minimum of $-3.1 \%$ at $8.6 \mathrm{ka}$, where after $\delta^{13} \mathrm{C}_{\text {calcite }}$ remains relatively constant through to present averaging $+0.4 \%$ apart from one prevalent positive excursion from 2 to $1.5 \mathrm{ka}$ of $+0.9 \%$. There are several short-term excursions shown across multiple proxies (e.g. 8.2, 3.4, 2.0 and 0.5 ka; Fig. 3).

\section{Discussion}

Sources of organic matter in the Lake Ohrid sedimentary record based on TOC/N and Rock Eval data

The Lake Ohrid sediments show fluctuations in TOC, $\mathrm{TOC} / \mathrm{N}$ and $\mathrm{HI}$, which generally have an inverse

Krevelen-type discrimination plot with thermal alteration pathways for OM Types I, II and III, and alteration pathway of Type I and II material during oxidation to Type III (grey dashed lines; after Meyers and Lallier-Verges 1999)

relationship with $\mathrm{OI}$ and $\delta^{13} \mathrm{C}_{\text {organic }}$ (Fig. 4). These relationships are seen during both short-term events (e.g. at $\approx 8.2$ or $2.0 \mathrm{ka}$ ) and as broad changes that define three main zones (Fig. 3).

The OM contained within a lake sediment record represents past changes in organic production, catchment vegetation and the amount of particulate and dissolved material transferred to the lake, as well as degradation and dilution effects resulting from differing abundances of inorganic components (Meyers and Teranes 2001). OM is made up of a compound mixture of lipids, carbohydrates and proteins, amongst other constituents produced by organisms that lived both within the lake and in the surrounding catchment (Meyers 2003). The total autochthonous and allochthonous $\mathrm{OM}$ in the sedimentary record may only represent a small 
fraction of that originally produced due to oxidation during settling prior to its incorporation into the sediment. It is suggested that bulk organic content still retains important source information even if over $90 \%$ is lost through degradation (Meyers and Eadie 1993; Meyers et al. 1995; Hodell and Schelske 1998). The TOC/N ratio and the HIOI data especially are used to estimate the origin of OM and ultimately establish whether organic sedimentation was dominated by endogenic or exogenic processes (Talbot and Livingstone 1989; Meyers and Teranes 2001).

The TOC/N ratio of OM is used to distinguish primary source location differentiated by the separation of vascular and non-vascular plant compositions, and TOC/N is lower (generally $<10$ ) in aquatic plants (Talbot and Johannessen 1992), whereas TOC/N is higher ( $>20)$ in vascular plants (Meyers and Teranes 2001; Leng and Marshall 2004). The $\mathrm{TOC} / \mathrm{N}$ ratio of Co1262 fluctuates but in general is below 10 (Fig. 3), with a mean $=8.8( \pm 1.2,1 \sigma)$ ranging between 5.5 and 11.2. TOC/N suggests that aquatic plants (probably phytoplankton) comprise the predominance of $\mathrm{OM}$ through the core. However, the lowest TOC/N could be due to selective decomposition (Leng et al. 2010).

Rock Eval pyrolysis is used here to identify and characterise potential source components. The most useful derived measurements from Rock Eval pyrolysis for lake studies are the HI and the OI, which are thought to reflect the origin of sedimentary OM (Meyers and Teranes 2001) and compliment TOC/N data. Three main types of $\mathrm{OM}$ (Types I, II and III) are distinguished using a van Krevelentype HI-OI diagram, but these types are also controlled by the degree of oxidation and alteration during thermal maturation (Talbot and Livingstone 1989). Type I sediments arise from material that is rich in hydrocarbons from microbial biomass or waxy land plants, Type II from algal OM and Type III from woody plant material (Meyers and Teranes 2001). The data from Co1262 show both Type II and Type III OM, which fall on a curve of changing OI suggesting a differential amount of oxidation either as a product of source changes or degradation (Fig. 4e). The curve is not temporally disturbed, so the changes are the result of climate or environmental change at the time of deposition and are not due to a progressive variation (Leng et al. 2013). In general, $\mathrm{HI}$ and $\mathrm{OI}$ are indirectly correlated $\left(R^{2}=0.5\right.$, Fig. 4e) and mostly represent Type II sediments (higher HI and lower OI). Zones III and I have a small fraction of Type III dominated (low HI and high OI) sediments. HI exhibits much greater variation than $\mathrm{OI}$ and also is positively correlated with changes in TOC/N $\left(R^{2}=0.6\right.$, Fig. $\left.4 \mathrm{a}\right)$, which suggests a dominantly algal source of OM. If organic proxies tracked variations in the amounts of aquatic and terrigenous material in the sediment, due to the compositional variation a positive correlation between TOC/N and OI would be expected and a negative correlation between TOC/N and HI. Major excursions are therefore the likely product of selective degradation, as with low TOC/N (Fig. 4a, b), rather than being caused by $\mathrm{OM}$ source changes.

Carbon isotope composition of organic matter from Lake Ohrid

As TOC/N and Rock Eval data suggest the sediment OM to be mostly pure algal material, $\delta^{13} \mathrm{C}_{\text {organic }}$ should record past variations in the aquatic carbon cycle (Leng et al. 2010). Even after degradation, as with TOC/N, bulk sediments are thought to retain primary signatures and preserve relative isotope variations (Meyers et al. 1995; Hodell and Schelske 1998). Within hard water lakes, such as Lake Ohrid, algae utilise dissolved $\mathrm{HCO}_{3}{ }^{-}$and therefore $\delta^{13} \mathrm{C}_{\text {organic }}$ will likely be a product of changes in the isotopic composition of the dissolved bicarbonate; changes due to fluctuations in productivity rates and surface nutrient availability are also possible (Leng et al. 2013). Secondary effects may be a mixture of variations in $\mathrm{pH}$, temperature and growth rate (Meyers and Teranes 2001). Phytoplankton within the lake will preferentially use ${ }^{12} \mathrm{C}$ to form $\mathrm{OM}$ that averages $20 \%$ lighter than the dissolved inorganic carbon source, and so changes in carbon supply can have a significant effect on $\delta^{13} C_{\text {organic }}$ (Leng et al. 2005). One major carbon source is likely to be isotopically light soil-derived $\mathrm{CO}_{2}$ $\left(\delta^{13} \mathrm{C}=-32\right.$ to $-20 \%$ ) formed by the decay of terrestrial organic matter, however, as $\mathrm{HCO}_{3}{ }^{-}$is the dominant carbon species $\left(\delta^{13} \mathrm{C} \approx+10 \%\right.$ o higher than $\mathrm{CO}_{2}$; Meyers and Teranes 2001), the dissolved $\mathrm{HCO}_{3}{ }^{-} \delta^{13} \mathrm{C}$ should be in the region of -22 to $-10 \%$ (Leng and Marshall 2004). Values from Co1262 imply a lake water $\delta^{13} \mathrm{C}_{\text {DIC }}$ source of approximately -9 to $-5 \%$ as $\delta^{13} \mathrm{C}_{\text {organic }}$ ranges between -29 and $-25 \%$ (Fig. 3), which suggests the bicarbonate pool may have had a secondary more enriched carbon source. A probable origin for the heavier carbon is from the dissolution of the karst aquifer rocks, known to have average $\delta^{13} \mathrm{C}=+1 \%$ o (Leng et al. 2010). Therefore, excursions in $\delta^{13} \mathrm{C}_{\text {organic }}$ through the core most probably correspond to periods of enhanced or reduced soil-derived carbon delivery to the lake. In general, $\delta^{13} \mathrm{C}_{\text {organic }}$ is higher in Zone III, decreases through Zone II to a minimum between approximately 5 and $3.5 \mathrm{ka}$, then becomes more variable through Zone I. $\delta^{13} \mathrm{C}_{\text {organic }}$ broadly follows a diversification in catchment arboreal pollen types (expansion of woodland) through the early Holocene and the associated development of rich organic soils (Panagiotopoulos et al. 2013).

\section{Oxygen isotope composition of calcite from Lake Ohrid}

During the spring-summer, when lake surface temperatures reach up to $27{ }^{\circ} \mathrm{C}$, (Matzinger et al. 2006b) calcite will be precipitated in the epilimnion by photoautotrophic organisms 


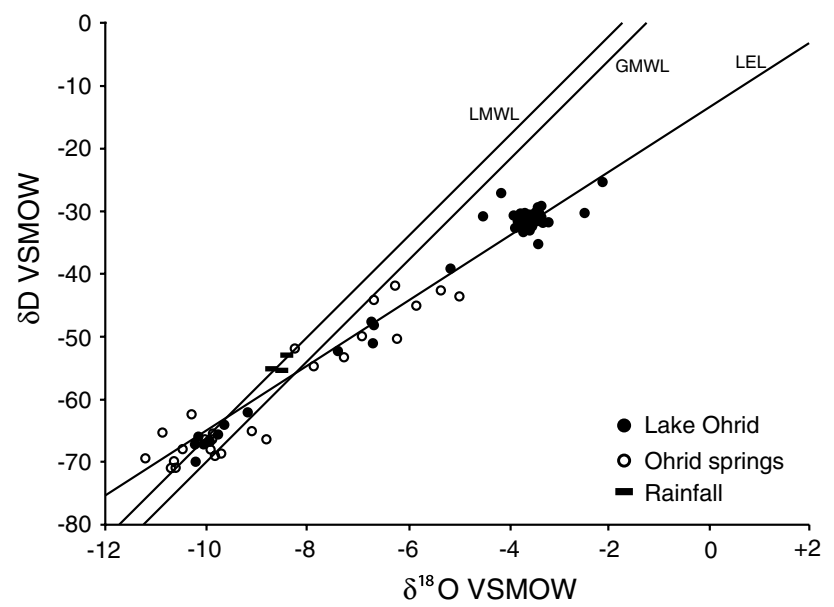

Fig. 5 The isotope composition $\left(\delta^{18} \mathrm{O}\right.$ and $\left.\delta \mathrm{D}\right)$ of modern waters from Lake Ohrid and several surrounding springs; the global meteoric water line (GMWL) and the local meteoric water line (LMWL) are shown as well as the local evaporation line (LEL) characterised by the isotopic composition of present day lake waters (Leng et al. 2010 and references therein)

that capture the oxygen isotope composition of lake water $\left(\delta^{18} \mathrm{O}_{\text {lakewater }}\right)$ at a given temperature. Thus, $\delta^{18} \mathrm{O}_{\text {calcite }}$ is a function of both the temperature and $\delta^{18} \mathrm{O}_{\text {lakewater }}$ in which it formed (Leng and Marshall 2004). The variation in isotopic composition over time records the evolution of the water body (Talbot 1990). Calcite precipitation requires an adequate supply of $\mathrm{Ca}^{2+}$ and $\mathrm{HCO}_{3}^{-}$, which in Lake Ohrid is mainly replenished by springs fed from Lake Prespa and concentrated by evaporation (Leng et al. 2013). SEM investigations of the calcite in Lake Ohrid have reported $<30 \mu \mathrm{m}$ idiomorphic calcite crystals (Matter et al. 2010) that are typical of endogenic-type precipitation (Belmecheri et al. 2009; Leng et al. 2010; Lézine et al. 2010).

The present day isotopic composition of waters from Lake Ohrid and of springs within the catchment has $\delta^{18} \mathrm{O}$ ranging between -10.2 and $+1.2 \%$ and $\delta \mathrm{D}$ between -69.9 and $-12.9 \%$ (Fig. 5). These data define a local evaporation line (LEL) which is distinct from the global meteoric water line (GMWL) and indicates Lake Ohrid water is evaporating. $\delta^{18} \mathrm{O}_{\text {lakewater }}$ is therefore a function of inflow (from the karst springs and direct rainfall) and water loss through evaporation, meaning any lower magnitude temperature or source variation signal will be unquantifiable (Leng and Marshall 2004). Lake Ohrid has a large water volume of $55 \mathrm{~km}^{3}$ and a long residence time of 70 years (Matzinger et al. 2006b), which means it has likely reached a steady state where short-term variations in the input and output are subdued. Any changes in lake water isotope composition are therefore the most likely result of low-frequency (centennial) climate variations (Leng et al. 2010). In general, within Lake Ohrid, high TIC phases have higher $\delta^{18} \mathrm{O}_{\text {calcite }}$ representing a reduced input/evaporation (I/E) ratio, while low TIC phases have lower $\delta^{18} \mathrm{O}_{\text {calcite }}$ from an increased $\mathrm{I} / \mathrm{E}$ ratio. The amount of climate signal captured within the endogenic calcites is directly a function of the temporal resolution of the sample size, higher frequency variations will be recorded where sedimentation rates are higher.

\section{Carbon isotope composition of calcite from Lake Ohrid}

Modern water data (Fig. 5) show Lake Ohrid to be sensitive to moisture balance (I/E), however, the lake displays little covariance between $\delta^{18} \mathrm{O}_{\text {calcite }}$ and $\delta^{13} \mathrm{C}_{\text {calcite }}\left(R^{2} \leq 0.1\right.$, Fig. 4f) which is normally associated with (open) water bodies that have shorter residence times (Talbot 1990). Generally, in evaporating (closed) lakes, $\delta^{18} \mathrm{O}$ variations are primarily related to water balance fluctuations and $\delta^{13} \mathrm{C}$ variations are influenced by the preferential outgassing of ${ }^{12} \mathrm{C}$-rich $\mathrm{CO}_{2}$ and exchange with atmospheric $\mathrm{CO}_{2}$ (Talbot and Kelts 1990). Hence, it has been suggested that the degree of palaeohydrological closure can be estimated by the extent of $\delta^{18} \mathrm{O}$ and $\delta^{13} \mathrm{C}$ covariance (Talbot 1990). However, this trend is not evident in Co1262 and is unclear across Mediterranean palaeo-lake datasets indicating that covariance is an unreliable gauge of hydrological balance within the region (Roberts et al. 2008; Leng et al. 2010).

$\delta^{13} \mathrm{C}_{\text {calcite }}$ within Lake Ohrid is relatively stable through the majority of the core $(<9 \mathrm{ka}$; average $\delta^{13} \mathrm{C}_{\text {calcite }}=+0.4 \pm 0.5 \%$ o, $\left.1 \sigma\right)$ with higher and more variable values in the Early Holocene up to $+1.8 \%$ o. $\delta^{13} \mathrm{C}_{\text {calcite }}$ ranges between -3.1 and $+1.8 \%$ and implies past lake water $\delta^{13} \mathrm{C}_{\mathrm{TDIC}}$ between -4.1 and $+0.8 \%$ o (due to a $+1 \%$ o enrichment between calcite and TDIC; Romanek et al. 1992). The extended residence time of lake water in Lake Ohrid and the relatively invariant $\delta^{13} \mathrm{C}_{\text {calcite }}$ suggest that the bicarbonate has likely reached a steady state indicating long-term stability between source and utilisation (Talbot and Kelts 1990; Leng et al. 2013). We might expect some photosynthetic control on the isotopic composition of the carbon pool due to removal of ${ }^{12} \mathrm{C}$ by aquatic organisms during times of heightened productivity, causing an increase in the isotopic composition of the carbon pool (assuming burial of organic matter; Andrews et al. 1993; Leng et al. 2013). However, as there is no substantial correlation between higher $\delta^{13} \mathrm{C}_{\text {calcite }}$ (or $\delta^{13} \mathrm{C}_{\text {organic }}$ ) and higher TIC and TOC content, changes in primary productivity are thought to have little effect on $\delta^{13} \mathrm{C}_{\mathrm{TDIC}}$ which is common for lakes with long residence times (Talbot and Kelts 1990). Other processes that could lower $\delta^{13} \mathrm{C}_{\mathrm{TDIC}}$ are limited in karstic region lakes to primarily the oxidation of $\mathrm{OM}$ and the input of soil-derived carbon (Leng et al. 2013). Oxidation of OM may be responsible for short-term changes in $\delta^{13} \mathrm{C}_{\mathrm{TDIC}}$ (e.g. between 8.5 and $8 \mathrm{ka}$ ) where OI increases coincident with lower $\delta^{13} \mathrm{C}_{\text {calcite }}$ and a reduction in both TIC and TOC. 
Late Glacial-Holocene organic matter and hydrological variability from Lake Ohrid

\section{Late Glacial to early Holocene (Zone III)}

In the first ca. $0.5 \mathrm{ka}$ of Zone III at the base of the core TOC, TOC/N and HI are all low and OI is high commensurate with the presence of gravel-sized grains which most likely represent ice-rafted debris (Wagner et al. 2009, 2012), suggesting that winter temperatures were low, productivity was at a minimum, and therefore, sedimentation was dominated by clastic input. A hiatus occurs around this time in a previous core (Lz1120) which is thought to be the result of subaquatic currents causing continuous erosion or the prevention of fine-grained sediment accumulation during low lake levels (Wagner et al. 2009). The low quantities of OM and TIC in the lowermost section of the core are therefore likely to be the result of a combined scenario of low productivity and dilution due to high clastic input. Enhanced lakewater circulation would also act to oxygenate lake waters, thereby increasing $\mathrm{OM}$ degradation and lead to higher OI values and lower $\mathrm{HI}$ and TOC/N which represent altered plant material (Talbot and Livingstone 1989). Less oxidation and higher productivity is suggested from $12 \mathrm{ka}$ by decreasing OI and increases in TOC, TOC/N and $\mathrm{HI}$ indicating the onset of warmer temperatures.

Zone III shows a consistent positive increase across organic proxies (except OI which decreases), although there is a short-term reversal after 10.4 ka which might be due to the dilution of OM components from increased TIC. A rise from $9.8 \mathrm{ka}$ in TOC, TOC/N and HI potentially indicates increased productivity and enhanced preservation of OM; during this period negligible TIC content could be linked to increased organic content and the addition of fresh water to the lake.

The interval between 8,500 and 8,000 cal. year BP (transition from Zone III to Zone II) is characterised by minima in TOC, TOC/N and $\mathrm{HI}$ and a peak in OI, alongside higher $\delta^{13} \mathrm{C}_{\text {organic }}$ and relatively low TIC $(<2 \%)$. Lower TIC, TOC and $\mathrm{HI}$ implies a reduction in primary productivity and carbonate precipitation and/or a higher potential for degradation and dissolution in a more oxygenated water column shown by higher OI. The excursions of proxies through this time approach values that are similar to the end of the core during the Late Glacial, where enhanced mixing and colder conditions prevailed (Wagner et al. 2009). Alongside cooling, aridity is suggested by higher $\delta^{13} \mathrm{C}_{\text {organic }}$ possibly the result of a reduction in run-off and the amount of soilderived carbon delivered to the lake. Increased aridity is also reported from pollen-based reconstructions from Lake Maliq (Albania; Bordon et al. 2009) and Tenaghi Philippon (Greece; Pross et al. 2009), where annual precipitation may have decreased by up to $250 \mathrm{~mm}$ through this time.
The aridity and cooling documented in Lake Ohrid occurs concomitant with negative excursions in Greenland ice core records (indicating cooling; Rasmussen et al. 2007), which are suggested to be the product of a perturbation to the North Atlantic meridional overturning circulation caused by the final drainage of Lake Agassiz into the North Atlantic ('8.2 kyr event'; Törnqvist and Hijma 2012). The record from Lake Ohrid is consistent with previous spatial reconstructions that infer much drier climate conditions for the Balkan Peninsula during a cooling phase in the Northern Hemisphere (Alley et al. 1997; Magny et al. 2003).

\section{Middle Holocene (Zone II)}

Within Zone II, TOC and HI have maximum values (at $5.2 \mathrm{ka}$ ) where a parallel rise is most likely due to a significant increase in aquatic algal productivity (Lojka et al. 2009). This is more typical of HI-OI Type II sediments (Fig. 4e) and TOC/N > 10 suggests a greater preservation of $\mathrm{OM}$ or potentially the incorporation of a minor amount of allochthonous material (high TOC/N). Increased rainfall and lakewater freshening is suggested by decreasing $\delta^{18} \mathrm{O}_{\text {calcite }}$, leading to enhanced inwash which is supported by progressively lower $\delta^{13} \mathrm{C}_{\text {organic }}$ resulting from enhanced delivery of soil-derived carbon.

An overall decrease is seen in many of the proxies through to Zone I, where TOC becomes increasingly variable after $4.5 \mathrm{ka}$. The decline in TOC, TOC/N and $\mathrm{HI}$ is most likely associated with lower temperatures and increasing aridity after $4 \mathrm{ka}$, which has been described previously in other Lake Ohrid cores (Wagner et al. 2008b, 2009; Vogel et al. 2010a) and in records from the wider Mediterranean region (e.g. Bar-Matthews et al. 1999; Magny et al. 2009). A short-term rapid decrease in TIC, TOC, TOC/N and $\mathrm{HI}$ occurs shortly after $3.4 \mathrm{ka}$, which is correlated with elevated $\mathrm{K}$ and low $\mathrm{H}_{2} \mathrm{O}$ content (Wagner et al. 2012) and is likely associated to the deposition of the Etna FL tephra at $3.37 \mathrm{ka}$ (Coltelli et al. 2000).

At $2 \mathrm{ka}$, there is a pronounced and rapid excursion within the Co1262 data where TOC drops to $<1 \%$, TOC/N to $<6$, HI to $<60$ and OI rises to $>550$. A maxima in OI indicate more extensive oxidation of $\mathrm{OM}$, which is supported by minimum values for $\mathrm{TOC} / \mathrm{N}$ and $\mathrm{HI}$ being the result of decompositional processes rather than source variation (Talbot and Livingstone 1989; Meyers and Ishiwatari 1995) and decreasing $\delta^{13} \mathrm{C}_{\text {calcite }}$ from the recycling of autochthonous OM. At this time, anthropogenic impact in the catchment is thought to be enhanced, including significant forest clearance and greater agricultural activity leading to higher erosion rates (Vogel et al. 2010a; Aufgebauer et al. 2012). Greater erosion would lead to an increased delivery of finegrained clastic material to the lake, seen as a $\mathrm{K}$ and sedimentation rate peak in Co1262 (Wagner et al. 2012), and 
also to an enhanced supply of nutrients and $\mathrm{OM}$. This $\mathrm{OM}$ would be readily oxidised, causing the release of $\mathrm{CO}_{2}$ and a decrease in bottom water $\mathrm{pH}$.

\section{Late Holocene to Present (Zone I)}

Following the transition from Zone II to Zone I, TIC and TOC are generally higher through to roughly $0.5 \mathrm{ka}$, which suggests an increase in productivity and a reduction in both mixing and decomposition of OM. Around this time, there was a substantial lake level drop in nearby Lake Prespa, which could have had a profound effect on Lake Ohrid's productivity as waters delivered through karstic springs contain significant amounts of bioavailable elements such as phosphorous (Matzinger et al. 2006a). Reduction of the water level of Lake Prespa may lead to an increased trophic state in Lake Ohrid and the potential for an enhanced phosphorous load to be transferred (Matzinger et al. 2006a; Wagner et al. 2009). There is an associated $\mathrm{K}$ decrease in Co1262 through this interval (Wagner et al. 2012), which could be related to increased catchment vegetation reducing erosion; as shown by higher AP percentages in pollen data from Lz1120 (Lake Ohrid; Wagner et al. 2009) and Co1215 (Lake Prespa; Aufgebauer et al. 2012). This may also be related to a decrease in recharge and increased aridity associated with a minor elevation in summer temperatures, indicated by pollen-based reconstructions from Lake Maliq (Bordon et al. 2009), which can be correlated to a warmer climate during the Medieval Warm Period $(\approx 1-$ $0.7 \mathrm{ka}$; Crowley and Lowery 2000). Lower values for TIC and TOC after $0.5 \mathrm{ka}$ indicate reduced primary productivity and a slight elevation in OI suggests a return to more oxygenating conditions and an associated increase in $\mathrm{OM}$ decomposition. These observations correlate with colder temperatures attributed to the Little Ice Age, observed in other records from Lake Ohrid and the surrounding region (Wagner et al. 2009; Aufgebauer et al. 2012; Francke et al. 2013).

In recent years $(<0.15 \mathrm{ka}), \mathrm{OM}$ concentrations have started to increase, which may be the result of anthropogenic eutrophication (Matzinger et al. 2007). However, the changes seen during the Late Holocene show that a signal of natural climate variability is preserved within the lake sediments and has not been completely overridden by anthropogenic activity.

Comparison of oxygen isotope composition between Lake Ohrid and other eastern Mediterranean lakes

\section{Late Glacial to Holocene transition}

High $\delta^{18} \mathrm{O}_{\text {calcite }}$ through the Younger Dryas is seen across Mediterranean lake records (e.g. Lake Van, Wick et al.
2003; Lake Frassino, Baroni et al. 2006), which may be linked to aridity associated with North Atlantic Heinrich events (Roberts et al. 2008). In Lake Ohrid, previous studies have suggested low lake levels coincident with stronger wind intensities (Vogel et al. 2010a) and higher $\delta^{18} \mathrm{O}_{\text {calcite }}$ is seen both Lake Ohrid and Lake Prespa (Fig. 6a). This is interpreted as a reduction in winter rainfall and greater summer aridity, conditions characteristic of the Younger Dryas where annual precipitation decreased by up to $50 \%$ across the Aegean region (Kotthoff et al. 2011).

\section{Early Holocene}

After the Younger Dryas high $\delta^{18} \mathrm{O}_{\text {calcite }}$ phase (post-10 ka), $\delta^{18} \mathrm{O}_{\text {calcite }}$ are at a minimum. This change is common across almost all Mediterranean lakes (e.g. Lake Eski Acigöl and Lake Zeribar; Fig. 6b) and is probably linked to increased freshwater input due to warmer and wetter conditions during the early Holocene, also recorded as a negative shift of ca. $4 \%$ in Soreq cave speleothems (Bar-Matthews et al. 2003). This is also seen as a maximum lake level in the Dead Sea (Frumkin 1997) and wetter conditions as recorded in $\delta^{18} \mathrm{O}$ of land snail shells (Goodfriend 1991). This low $\delta^{18} \mathrm{O}$ phase is coincident with the formation of marine sapropel I in the Mediterranean Sea, which is considered to originate from greater precipitation rates causing freshening of surface waters (Kallel et al. 1997; Kotthoff et al. 2008) combined with increased inflow from the river Nile both acting to create a freshwater surface layer and subsequent bottom water anoxia between 9.5 and $6.5 \mathrm{ka}$ in the Mediterranean Sea (Rohling 1994; Ariztegui et al. 2000). During this time, other lakes from around the Mediterranean remain isotopically fresh shown by relatively sustained low $\delta^{18} \mathrm{O}$ values (Fig. 6b; Roberts et al. 2008).

There is a shift to more positive $\delta^{18} \mathrm{O}_{\text {calcite }}$ values in Lake Ohrid between 8.6 and 8 ka suggesting increased aridity; at this time, lakes Prespa, Gölhisar and Zeribar show exemplified shifts likely due to their shorter lake water residence times and lower lake water volumes (Stevens et al. 2001; Eastwood et al. 2007; Leng et al. 2013). These positive $\delta^{18} \mathrm{O}_{\text {calcite }}$ are most likely linked to a drier climate in northern and southern Europe during the North Atlantic '8.2 event' (Alley et al. 1997), as part of a hydrological tri-partition at the time (Magny et al. 2003).

\section{Middle Holocene}

Lake Ohrid had less winter recharge from $7 \mathrm{ka}$, suggested by a general increase in $\delta^{18} \mathrm{O}_{\text {calcite }}$ assuming summer evaporation was not counteracted. This is in contrast to Lake Prespa where recharge was sufficient due to a lower lakewater volume to catchment area ratio (Leng et al. 2010). At Lake Gölhisar, $\delta^{18} \mathrm{O}_{\text {calcite }}$ also increases through this time 

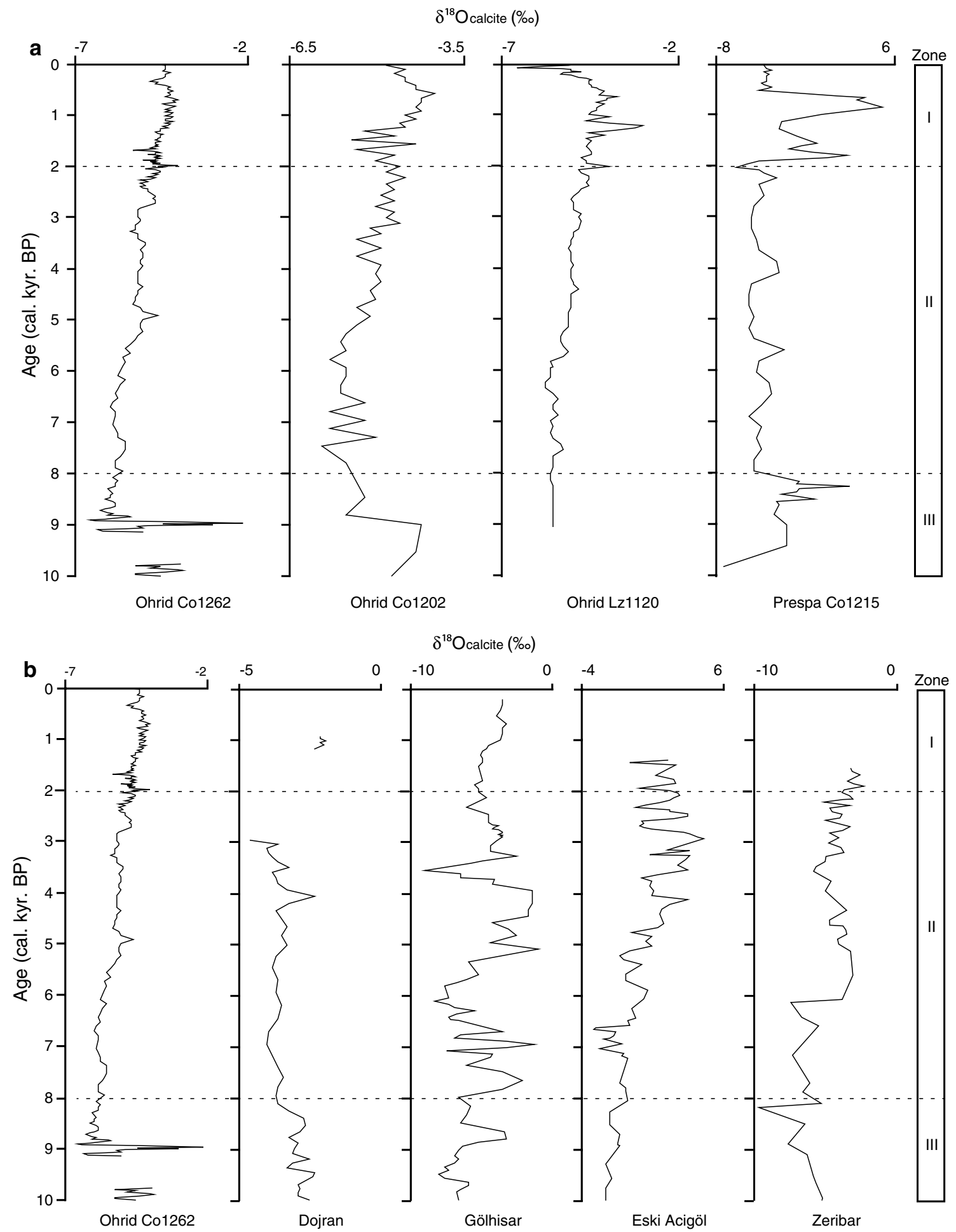

Fig. 6 a Comparison of $\delta^{18} \mathrm{O}_{\text {calcite }}$ between core Co1262 and previous records from Lake Ohrid and Lake Prespa. b Comparison of $\delta^{18} \mathrm{O}_{\text {calcite }}$ between $\mathrm{Co} 1262$ and other records from the eastern Mediterranean region (Fig. 1; Ohrid Co1202, Vogel et al. 2010a; Ohrid
Lz1120, Wagner et al. 2010; Prespa Co1215, Leng et al. 2013; Dojran, Francke et al. 2013; Gölhisar, Eastwood et al. 2007; Eski Acigöl, Roberts et al. 2001; Zeribar, Stevens et al. 2001); dashed lines indicate zones described in this paper (Fig. 3) 
period, however, there is also a higher degree of variability as the lake responds very rapidly to moisture balance changes (Eastwood et al. 2007). Lake Eski Acigöl and Lake Zeribar shift to higher $\delta^{18} \mathrm{O}_{\text {calcite }}$ values from around $7 \mathrm{ka}$ (Roberts et al. 2001; Stevens et al. 2001). At Lake Dojran $\delta^{18} \mathrm{O}_{\text {calcite }}$ values remain relatively constant from $7 \mathrm{ka}$ (Francke et al. 2013), but have lower $\delta^{18} \mathrm{O}_{\text {calcite }}$ prior to this, which is most likely due to the shallow bathymetry of the lake. A minor drop in lake level results in a large drop in surface area greatly reducing evaporation leading to lower $\delta^{18} \mathrm{O}_{\text {calcite }}$ (Francke et al. 2013). Overall though, eastern Mediterranean lakes have low and stable $\delta^{18} \mathrm{O}_{\text {calcite }}$ values through the middle Holocene, with variable $\delta^{18} \mathrm{O}_{\text {calcite }}$ due to site-specific variations (Fig. 6; Zanchetta et al. 2007a; Roberts et al. 2008; Develle et al. 2010; Leng et al. 2013).

Generally, high $\delta^{18} \mathrm{O}_{\text {calcite }}$ values are seen between 6 and $4 \mathrm{ka}$ in Lake Gölhisar and Lake Zeribar (Stevens et al. 2001; Eastwood et al. 2007), with a shorter-term event recorded in Lake Prespa, Dojran and Eski Acigöl between 4.3 and 3.9 ka (Roberts et al. 2001; Francke et al. 2013; Leng et al. 2013). This might correlate to the $4.2 \mathrm{ka}$ event, described previously from the OM data in Lake Ohrid (Sect. 5.5.2), which has been interpreted as a short period of cooler temperatures and more arid conditions comparable to other Mediterranean records (e.g. Bar-Matthews et al. 1999; Magny et al. 2009; Vogel et al. 2010a). Temperature reconstructions from the surrounding Aegean (Rohling et al. 2002) and Adriatic Seas (Sangiorgi et al. 2003) concur with cooling, whilst dry conditions are promoted by reduced moisture availability from the Atlantic during positive North Atlantic Oscillation (Lamy et al. 2006) which is correlated with a strong drop in African lake levels resulting from a weakening of the African monsoon (Kröpelin et al. 2008; Magny et al. 2009).

\section{Late Holocene}

Lake Ohrid shows sustained high $\delta^{18} \mathrm{O}_{\text {calcite }}$ from $2 \mathrm{ka}$ until around $0.5 \mathrm{ka}$ which is also recorded across a range of Mediterranean lakes (Roberts et al. 2008) and speleothems (Bar-Matthews et al. 2000; Zanchetta et al. 2007b). Notable, is the large positive excursion in Lake Prespa interpreted as the result of a significant lake level drop (see Sect. 5.5.3; Leng et al. 2010). Leading up to and through this time period Northern Europe was cooler due to a decrease in solar insolation (Van Geel et al. 2000; Wanner et al. 2008), which may have caused the pattern of regional aridification by reducing moisture advection from the Atlantic (Leng et al. 2013). This is also seen in a weakening of the African monsoon and the onset of dry conditions in the Sahara (Gasse 2000).

Fresher lake water conditions are suggested from $0.5 \mathrm{ka}$ by lower $\delta^{18} \mathrm{O}_{\text {calcite }}$ in $\mathrm{Co1262}$, however, not to the extent of other Lake Ohrid and Lake Prespa records (Vogel et al. 2010a; Wagner et al. 2010; Leng et al. 2013). The degree of freshening may in part be related to changes in Lake Prespa, which for this time had $\delta^{18} \mathrm{O}_{\text {calcite }}$ of $\approx-7 \%$; these waters would have been transferred to Lake Ohrid through the karst aquifer network. An overall freshening of the lake might also be associated with forest clearance and anthropogenic change (Wagner et al. 2009), where a more direct route for rainfall from catchment to lake would result in lake waters reflecting lower $\delta^{18} \mathrm{O}_{\text {rainfall }}$. In recent years, apparent freshening has been enhanced where changes in water balance have been anthropogenically controlled by the use of tributaries for agricultural irrigation (Matzinger et al. 2006b) and the 1962 diversion of the River Sateska into Lake Ohrid (Leng et al. 2010).

\section{Conclusions}

Here, new stable isotope and geochemical data from core Co1262 (the highest resolution and best-dated record from Lake Ohrid to date) provides valuable information on local climate and hydrological variations through the Late Glacial to Holocene.

The sedimentary sequence from Lake Ohrid have been divided into three main zones based mainly on changes in the organic and inorganic content of the sediments. The lowermost part of Zone III (>12 ka) suggests low productivity and reduced groundwater recharge. The lake water would have been well oxygenated promoting OM degradation. Warmer temperatures through the rest of this zone might have been the cause of increased lacustrine and catchment productivity. At the transition from Zone III to Zone II, an event between 8.6 and 8.0 ka suggests a return to colder conditions and lower productivity, most likely the response in Lake Ohrid to the $8.2 \mathrm{ka}$ cooling event. Zone II shows an initial increase in aquatic productivity and terrestrial input through a warm and stable period. From $4.5 \mathrm{ka}$, OM content becomes more variable following lower temperatures and aridity, a prevalent negative excursion occurs after 3.4 ka coincident with the deposition of the Etna FL tephra. Within an overall change to more positive $\delta^{18} \mathrm{O}_{\text {calcite }}$ (greater aridity) through the Holocene are several rapid arid events, which due to confidence in the dating, appear to match temporally with concomitant excursions in Lake Prespa. A significant short-term excursion is recorded at $2 \mathrm{ka}$ across all datasets to pre-Holocene levels. At this time, anthropogenic activity is documented to have had a widespread influence on catchment vegetation through forest clearance leading to higher erosion. Short-term climate variations are seen in the most recent record, in particular increased productivity around $1 \mathrm{ka}$ and the subsequent decrease likely represents the response to the Medieval 
Warm Period and the Little Ice Age. Recent increases in $\mathrm{OM}$ concentrations are probably linked to anthropogenic eutrophication.

The data from Co1262 fits both temporally and spatially into what is known about Late Glacial to Holocene climate across the Mediterranean but both at a higher resolution and with a better chronology. The data and interpretations will give context for a reconstruction of climate and hydrology for the Scientific Collaboration On Past Speciation Conditions in Lake Ohrid (SCOPSCO) cores over the entire lake history, which likely goes back to the Lower Pleistocene (Wagner et al. 2014).

Acknowledgments The study was funded by the German Research Foundation (WA 2109/11) and by the International Continental scientific Drilling Program (ICDP); it forms part of the $\mathrm{PhD}$ research (of JHL) funded by the British Geological Survey University Funding Initiative (BUFI) and also the $\mathrm{PhD}$ (of $\mathrm{AF}$ ) in Cologne. Thanks go to Andrea Snelling and Chris Kendrick for help and training with the isotope analysis.

\section{References}

Albrecht C, Wilke T (2008) Ancient Lake Ohrid: biodiversity and evolution. Hydrobiologia 615(1):103-140

Aliaj S, Baldassarre G, Shkupi D (2001) Quaternary subsidence zones in Albania: some case studies. Bull Eng Geol Environ 59(4):313-318

Alley RB, Mayewski PA, Sowers T, Stuiver M, Taylor KC, Clark PU (1997) Holocene climatic instability: a prominent, widespread event 8200 yr ago. Geology 25(6):483-486

Andrews JE, Riding R, Dennis PF (1993) Stable isotopic compositions of recent freshwater cyanobacterial carbonates from the British Isles: local and regional environmental controls. Sedimentology 40(2):303-314

Ariztegui D, Asioli A, Lowe JJ, Trincardi F, Vigliotti L, Tamburini F, Chondrogianni C, Accorsi CA, Bandini Mazzanti M, Mercuri AM, Van Der Kaars S, McKenzie JA, Oldfield F (2000) Palaeoclimate and the formation of sapropel S1: inferences from Late Quaternary lacustrine and marine sequences in the central Mediterranean region. Palaeogeogr Palaeoclimatol Palaeoecol 158(3-4):215-240

Aufgebauer A, Panagiotopoulos K, Wagner B, Schaebitz F, Viehberg FA, Vogel H, Zanchetta G, Sulpizio R, Leng MJ, Damaschke M (2012) Climate and environmental change in the Balkans over the last $17 \mathrm{ka}$ recorded in sediments from Lake Prespa (Albania/ F.Y.R. of Macedonia/Greece). Quat Int 274:122-135

Bar-Matthews M, Ayalon A, Kaufman A, Wasserburg GJ (1999) The Eastern Mediterranean paleoclimate as a reflection of regional events: Soreq cave, Israel. Earth Planet Sci Lett 166(1-2):85-95

Bar-Matthews M, Ayalon A, Kaufman A (2000) Timing and hydrological conditions of Sapropel events in the Eastern Mediterranean, as evident from speleothems, Soreq cave, Israel. Chem Geol 169(1-2):145-156

Bar-Matthews M, Ayalon A, Gilmour M, Matthews A, Hawkesworth CJ (2003) Sea-land oxygen isotopic relationships from planktonic foraminifera and speleothems in the Eastern Mediterranean region and their implication for paleorainfall during interglacial intervals. Geochim Cosmochim Acta 67(17):3181-3199

Baroni C, Zanchetta G, Fallick AE, Longinelli A (2006) Mollusca stable isotope record of a core from Lake Frassino, northern Italy: hydrological and climatic changes during the last 14 ka. Holocene 16(6):827-837

Belmecheri S, Namiotko T, Robert C, von Grafenstein U, Danielopol DL (2009) Climate controlled ostracod preservation in Lake Ohrid (Albania, Macedonia). Palaeogeogr Palaeoclimatol Palaeoecol 277(3-4):236-245

Blaauw M (2010) Methods and code for 'classical' age-modelling of radiocarbon sequences. Quat Geochronol 5:512-518

Bordon A, Peyron O, Lézine A-M, Brewer S, Fouache E (2009) Pollen-inferred Late-Glacial and Holocene climate in southern Balkans (Lake Maliq). Quat Int 200:19-30

Coltelli M, Del Carlo P, Vezzoli L (2000) Stratigraphic constraints for explosive activity in the past $100 \mathrm{ka}$ at Etna Volcano, Italy. Int $\mathrm{J}$ Earth Sci 89(3):665-677

Crowley TJ, Lowery TS (2000) How warm was the medieval warm period? Ambio 29(1):51-54

Dean JR, Jones MD, Leng MJ, Sloane HJ, Roberts CN, Woodbridge J, Swann GEA, Metcalfe SE, Eastwood WJ, Yiğitbaşığlu H (2013) Palaeo-seasonality of the last two millennia reconstructed from the oxygen isotope composition of carbonates and diatom silica from Nar Gölü, central Turkey. Quat Sci Rev $66: 35-44$

Develle AL, Herreros J, Vidal L, Sursock A, Gasse F (2010) Controlling factors on a paleo-lake oxygen isotope record (Yammoûneh, Lebanon) since the Last Glacial Maximum. Quat Sci Rev 29(7-8):865-886

Eastwood WJ, Leng MJ, Roberts N, Davis B (2007) Holocene climate change in the eastern Mediterranean region: a comparison of stable isotope and pollen data from Lake Gölhisar, southwest Turkey. J Quat Sci 22(4):327-341

Francke A, Wagner B, Leng MJ, Rethemeyer J (2013) A Late Glacial to Holocene record of environmental change from Lake Dojran (Macedonia, Greece). Clim Past 9(1):481-498

Frumkin A (1997) The Holocene history of Dead Sea levels. In: Niemi TM, Ben-Avraham Z, Gat JR (eds) The Dead Sea: the lake and its setting. Oxford monographs on geology and geophysics, vol 36. Oxford University Press, Oxford, pp 237-248

García-Ruiz JM, López-Moreno JI, Vicente-Serrano SM, LasantaMartínez T, Beguería S (2011) Mediterranean water resources in a global change scenario. Earth Sci Rev 105(3-4):121-139

Gasse F (2000) Hydrological changes in the African tropics since the Last Glacial Maximum. Quat Sci Rev 19(1-5):189-211

Giannakopoulos C, Le Sager P, Bindi M, Moriondo M, Kostopoulou E, Goodess CM (2009) Climatic changes and associated impacts in the Mediterranean resulting from a $2{ }^{\circ} \mathrm{C}$ global warming. Glob Planet Change 68(3):209-224

Goodfriend GA (1991) Holocene trends in 180 in land snail shells from the Negev Desert and their implications for changes in rainfall source areas. Quat Res 35(3, 1):417-426

Hadzisce S (1966) Das Mixophänomen im Ohridsee im Laufe der Jahre 1941/42-1964/65. Verhandlungen des Internationalen Verein Limnologie 16:134-138

Hodell DA, Schelske CL (1998) Production, sedimentation, and isotopic composition of organic matter in Lake Ontario. Limnol Oceanogr 43(2):200-214

Hoffmann N, Reicherter K, Grützner C, Hürtgen J, Rudersdorf A, Viehberg FA, Wessels M (2012) Quaternary coastline evolution of Lake Ohrid (Macedonia/Albania). Cent Eur J Geosci 4(1):94-110

Kallel N, Paterne M, Duplessy JC, Vergnaud-Grazzini C, Pujol C, Labeyrie L, Arnold M, Fontugne M, Pierre C (1997) Enhanced rainfall in the Mediterranean region during the last sapropel event. Oceanol Acta 20(5):697-712

Kotthoff U, Muller UC, Pross J, Schmiedl G, Lawson IT, van de Schootbrugge B, Schulz H (2008) Lateglacial and Holocene vegetation dynamics in the Aegean region: an integrated view based 
on pollen data from marine and terrestrial archives. Holocene 18(7):1019-1032

Kotthoff U, Koutsodendris A, Pross J, Schmiedl G, Bornemann A, Kaul C, Marino G, Peyron O, Schiebel R (2011) Impact of Lateglacial cold events on the northern Aegean region reconstructed from marine and terrestrial proxy data. J Quat Sci 26(1):86-96

Kröpelin S, Verschuren D, Lézine AM, Eggermont H, Cocquyt C, Francus P, Cazet JP, Fagot M, Rumes B, Russell JM, Darius F, Conley DJ, Schuster M, Von Suchodoletz H, Engstrom DR (2008) Climate-driven ecosystem succession in the Sahara: the past 6000 years. Science 320(5877):765-768

Lamy F, Arz HW, Bond GC, Bahr A, Pätzold J (2006) Multicentennial-scale hydrological changes in the Black Sea and northern Red Sea during the Holocene and the Arctic/North Atlantic oscillation. Paleoceanography 21:PA1008

Leng MJ, Marshall JD (2004) Palaeoclimate interpretation of stable isotope data from lake sediment archives. Quat Sci Rev 23(7-8):811-831

Leng MJ, Lamb AL, Heaton THE, Marshall JD, Wolfe BB, Jones MD, Holmes JA, Arrowsmith C (2005) Isotopes in lake sediments. In: Leng MJ (ed) Isotopes in palaeoenvironmental research. Springer, Dordrecht, pp 148-176

Leng MJ, Baneschi I, Zanchetta G, Jex CN, Wagner B, Vogel H (2010) Late Quaternary palaeoenvironmental reconstruction from Lakes Ohrid and Prespa (Macedonia/Albania border) using stable isotopes. Biogeosciences 7(10):3109-3122

Leng MJ, Wagner B, Boehm A, Panagiotopoulos K, Vane CH, Snelling A, Haidon C, Woodley E, Vogel H, Zanchetta G, Baneschi I (2013) Understanding past climatic and hydrological variability in the Mediterranean from Lake Prespa sediment isotope and geochemical record over the Last Glacial cycle. Quat Sci Rev 66:123-136

Lézine AM, von Grafenstein U, Andersen N, Belmecheri S, Bordon A, Caron B, Cazet JP, Erlenkeuser H, Fouache E, Grenier C, Huntsman-Mapila P, Hureau-Mazaudier D, Manelli D, Mazaud A, Robert C, Sulpizio R, Tiercelin JJ, Zanchetta G, Zeqollari Z (2010) Lake Ohrid, Albania, provides an exceptional multi-proxy record of environmental changes during the last glacial-interglacial cycle. Palaeogeogr Palaeoclimatol Palaeoecol 287(1-4):116-127

Lindhorst K, Krastel S, Reicherter K, Stipp M, Wagner B, Schwenk T (2014) Sedimentary and tectonic evolution of Lake Ohrid (Macedonia/Albania). Basin Res. doi:10.1111/bre.12063

Lojka R, Drábková J, Zajíc J, Sýkorová I, Franců J, Bláhová A, Grygar T (2009) Climate variability in the Stephanian B based on environmental record of the Mšec Lake deposits (KladnoRakovník Basin, Czech Republic). Palaeogeogr Palaeoclimatol Palaeoecol 280(1-2):78-93

Magny M, Bégeot C, Guiot J, Peyron O (2003) Contrasting patterns of hydrological changes in Europe in response to Holocene climate cooling phases. Quat Sci Rev 22(15-17):1589-1596

Magny M, Vannière B, Zanchetta G, Fouache E, Touchais G, Petrika L, Coussot C, Walter-Simonnet AV, Arnaud F (2009) Possible complexity of the climatic event around 4300-3800 cal. BP in the central and western Mediterranean. Holocene 19(6):823-833

Matter M, Anselmetti FS, Jordanoska B, Wagner B, Wessels M, Wüest A (2010) Carbonate sedimentation and effects of eutrophication observed at the Kališta subaquatic springs in Lake Ohrid (Macedonia). Biogeosciences 7(11):3755-3767

Matzinger A, Jordanoski M, Veljanoska-Sarafiloska E, Sturm M, Müller B, Wüest A (2006a) Is Lake Prespa jeopardizing the ecosystem of ancient Lake Ohrid? Hydrobiologia 553(1):89-109

Matzinger A, Spirkovski Z, Patceva S, Wüest A (2006b) Sensitivity of ancient Lake Ohrid to local anthropogenic impacts and global warming. J Great Lakes Res 32(1):158-179

Matzinger A, Schmid M, Veljanoska-Sarafiloska E, Patceva S, Guseska D, Wagner B, Müller B, Sturm M, Wüest A (2007)
Eutrophication of ancient Lake Ohrid: global warming amplifies detrimental effects of increased nutrient inputs. Limnol Oceanogr 52(1):338-353

Meyers PA (2003) Applications of organic geochemistry to paleolimnological reconstructions: a summary of examples from the Laurentian Great Lakes. Org Geochem 34(2):261-289

Meyers PA, Eadie BJ (1993) Sources, degradation and recycling of organic matter associated with sinking particles in Lake Michigan. Org Geochem 20(1):47-56

Meyers PA, Ishiwatari R (1995) Organic matter accumulation records in lake sediments. In: Lerman A, Imboden D, Gat J (eds) Physics and chemistry of lakes. Springer, Berlin, pp 279-328

Meyers PA, Lallier-Verges E (1999) Lacustrine sedimentary organic matter records of Late Quaternary paleoclimates. J Paleolimnol 21(3):345-372

Meyers PA, Teranes J (2001) Sediment Organic Matter. In: Last W, Smol J (eds) Tracking environmental change using lake sediments (2). Developments in paleoenvironmental research. Springer, Dordrecht, pp 239-269

Meyers PA, Leenheer MJ, Bourbonniere RA (1995) Diagenesis of vascular plant organic matter components during burial in lake sediments. Aquat Geochem 1:35-52

Panagiotopoulos K, Aufgebauer A, Schäbitz F, Wagner B (2013) Vegetation and climate history of the Lake Prespa region since the Lateglacial. Quat Int 293:157-169

Popovska C, Bonacci O (2007) Basic data on the hydrology of Lakes Ohrid and Prespa. Hydrol Process 21(5):658-664

Pross J, Kotthoff U, Muller UC, Peyron O, Dormoy I, Schmiedl G, Kalaitzidis S, Smith AM (2009) Massive perturbation in terrestrial ecosystems of the Eastern Mediterranean region associated with the 8.2 kyr B.P. climatic event. Geology 37(10):887-890

Rasmussen SO, Vinther BM, Clausen HB, Andersen KK (2007) Early Holocene climate oscillations recorded in three Greenland ice cores. Quat Sci Rev 26(15-16):1907-1914

Reicherter K, Hoffmann N, Lindhorst K, Krastel S, FernándezSteeger T, Grützner C, Wiatr T (2011) Active basins and neotectonics: morphotectonics of the Lake Ohrid Basin (FYROM and Albania). Zeitschrift der Deutschen Gesellschaft für Geowissenschaften 162(2):217-234

Reimer PJ, Baillie MGL, Bard E, Bayliss A, Beck JW, Blackwell PG, Ramsey CB, Buck CE, Burr GS, Edwards RL, Friedrich M, Grootes PM, Guilderson TP, Hajdas I, Heaton TJ, Hogg AG, Hughen KA, Kaiser KF, Kromer B, McCormac FG, Manning SW, Reimer RW, Richards DA, Southon JR, Talamo S, Turney CSM, van der Plicht J, Weyhenmeyer CE (2009) IntCal09 and Marine09 radiocarbon age calibration curves, 0-50,000 years CAL BP. Radiocarbon 51(4):1111-1150

Reimer PJ, Bard E, Bayliss A, Beck JW, Blackwell PG, Bronk Ramsey C, Buck CE, Cheng H, Edwards RL, Friedrich M, Grootes PM, Guilderson T, Haflidason H, Hajdas I, Hatté C, Heaton TJ, Hoffmann DL, Hogg AG, Hughen KA, Kaiser KF, Kromer B, Manning SW, Niu M, Reimer RW, Richards DA, Scott EM, Southon JR, Staff RA, Turney CSM, van der Plicht J (2013) IntCal13 and Marine13 radiocarbon age calibration curves 0-50,000 years cal BP. Radiocarbon 55(4):1869-1887

Roberts N, Reed JM, Leng MJ, Kuzucuoğlu C, Fontugne M, Bertaux J, Woldring H, Bottema S, Black S, Hunt E, Karabiyikoğlu M (2001) The tempo of Holocene climatic change in the eastern Mediterranean region: new high-resolution crater-lake sediment data from central Turkey. Holocene 11(6):721-736

Roberts N, Jones MD, Benkaddour A, Eastwood WJ, Filippi ML, Frogley MR, Lamb HF, Leng MJ, Reed JM, Stein M, Stevens L, Valero-Garcés B, Zanchetta G (2008) Stable isotope records of Late Quaternary climate and hydrology from Mediterranean lakes: the ISOMED synthesis. Quat Sci Rev 27(25-26):2426-2441 
Roelofs A, Kilham P (1983) The diatom stratigraphy and palaeoecology of lake Ohrid, Yugoslavia. Palaeogeogr Palaeoclimatol Palaeoecol 42(3-4):225-245

Rohling EJ (1994) Review and new aspects concerning the formation of eastern Mediterranean sapropels. Mar Geol 122(1-2):1-28

Rohling E, Mayewski P, Abu-Zied R, Casford J, Hayes A (2002) Holocene atmosphere-ocean interactions: records from Greenland and the Aegean Sea. Clim Dyn 18(7):587-593

Romanek CS, Grossman EL, Morse JW (1992) Carbon isotopic fractionation in synthetic aragonite and calcite: effects of temperature and precipitation rate. Geochim Cosmochim Acta 56(1):419-430

Rosenbaum J, Sheppard SMF (1986) An isotopic study of siderites, dolomites and ankerites at high temperatures. Geochim Cosmochim Acta 50(6):1147-1150

Sangiorgi F, Capotondi L, Combourieu Nebout N, Vigliotti L, Brinkhuis H, Giunta S, Lotter AF, Morigi C, Negri A, Reichart G-J (2003) Holocene seasonal sea-surface temperature variations in the southern Adriatic Sea inferred from a multiproxy approach. J Quat Sci 18(8):723-732

Stankovic S (1960) The Balkan Lake Ohrid and Its Living World (9). Monographiae Biologicae. Uitgeverij Dr. W. Junk, Den Haag

Stevens LR, Wright HE Jr, Ito E (2001) Proposed changes in seasonality of climate during the Lateglacial and Holocene at Lake Zeribar, Iran. Holocene 11(6):747-755

Stuiver M, Reimer PJ (1993) Extended 14C data base and revised CALIB 3.0 14C age calibration program. Radiocarbon 35(1):215-230

Sulpizio R, Zanchetta G, D’Orazio M, Vogel H, Wagner B (2010) Tephrostratigraphy and tephrochronology of lakes Ohrid and Prespa, Balkans. Biogeosci Discuss 7(3):3931-3967

Talbot MR (1990) A review of the palaeohydrological interpretation of carbon and oxygen isotopic ratios in primary lacustrine carbonates. Chem Geol Isot Geosci Sect 80(4):261-279

Talbot MR, Johannessen T (1992) A high resolution palaeoclimatic record for the last 27,500 years in tropical West Africa from the carbon and nitrogen isotopic composition of lacustrine organic matter. Earth Planet Sci Lett 110(1-4):23-37

Talbot MR, Kelts K (1990) Palaeolimnological signatures from carbon and oxygen isotopic ratios in carbonates from organic-rich lacustrine sediments. In: Katz BJ (ed) Lacustrine basin exploration: case studies and modern analogues. AAPG Meoir 50, pp 99-112

Talbot MR, Livingstone DA (1989) Hydrogen index and carbon isotopes of lacustrine organic-matter as lake level indicators. Palaeogeogr Palaeoclimatol Palaeoecol 70(1-3):121-137

Törnqvist TE, Hijma MP (2012) Links between early Holocene icesheet decay, sea-level rise and abrupt climate change. Nat Geosci 5(9):601-606

Van Geel B, Heusser CJ, Renssen H, Schuurmans CJE (2000) Climatic change in Chile at around $2700 \mathrm{BP}$ and global evidence for solar forcing: a hypothesis. Holocene 10(5):659-664

Vogel H, Wagner B, Zanchetta G, Sulpizio R, Rosén P (2010a) A paleoclimate record with tephrochronological age control for the last glacial-interglacial cycle from Lake Ohrid, Albania and Macedonia. J Paleolimnol 44(1):295-310

Vogel H, Zanchetta G, Sulpizio R, Wagner B, Nowaczyk N (2010b) A tephrostratigraphic record for the last glacial-interglacial cycle from Lake Ohrid, Albania and Macedonia. J Quat Sci 25(3):320-338

Wagner B, Reicherter K, Daut G, Wessels M, Matzinger A, Schwalb A, Spirkovski Z, Sanxhaku M (2008a) The potential of Lake Ohrid for long-term palaeoenvironmental reconstructions. Palaeogeogr Palaeoclimatol Palaeoecol 259(2-3):341-356

Wagner B, Sulpizio R, Zanchetta G, Wulf S, Wessels M, Daut G, Nowaczyk N (2008b) The last 40 ka tephrostratigraphic record of Lake Ohrid, Albania and Macedonia: a very distal archive for ash dispersal from Italian volcanoes. J Volcanol Geotherm Res 177(1):71-80

Wagner B, Lotter AF, Nowaczyk N, Reed JM, Schwalb A, Sulpizio R, Valsecchi V, Wessels M, Zanchetta G (2009) A 40,000-year record of environmental change from ancient Lake Ohrid (Albania and Macedonia). J Paleolimnol 41(3):407-430

Wagner B, Vogel H, Zanchetta G, Sulpizio R (2010) Environmental change within the Balkan region during the past ca. $50 \mathrm{ka}$ recorded in the sediments from lakes Prespa and Ohrid. Biogeosciences 7(10):3187-3198

Wagner B, Francke A, Sulpizio R, Zanchetta G, Lindhorst K, Krastel S, Vogel H, Rethemeyer J, Daut G, Grazhdani A, Lushaj B, Trajanovski S (2012) Possible earthquake trigger for 6th century mass wasting deposit at Lake Ohrid (Macedonia/Albania). Clim Past 8(6):2069-2078

Wagner B, Wilke T, Krastel S, Zanchetta G, Sulpizio R, Reicherter K, Leng M, Grazhdani A, Trajanovski S, Levkov Z, Reed J, Wonik $\mathrm{T}$ (2014) More than one million years of history in Lake Ohrid cores. EOS 95(3):25-26

Wanner H, Beer J, Bütikofer J, Crowley TJ, Cubasch U, Flückiger J, Goosse H, Grosjean M, Joos F, Kaplan JO, Küttel M, Müller SA, Prentice IC, Solomina O, Stocker TF, Tarasov P, Wagner M, Widmann M (2008) Mid- to Late Holocene climate change: an overview. Quat Sci Rev 27(19-20):1791-1828

Wick L, Lemcke G, Sturm M (2003) Evidence of Lateglacial and Holocene climatic change and human impact in eastern Anatolia: high-resolution pollen, charcoal, isotopic and geochemical records from the laminated sediments of Lake Van, Turkey. Holocene 13(5):665-675

Zanchetta G, Borghini A, Fallick AE, Bonadonna FP, Leone G (2007a) Late Quaternary palaeohydrology of Lake Pergusa (Sicily, southern Italy) as inferred by stable isotopes of lacustrine carbonates. J Paleolimnol 38(2):227-239

Zanchetta G, Drysdale RN, Hellstrom JC, Fallick AE, Isola I, Gagan MK, Pareschi MT (2007b) Enhanced rainfall in the Western Mediterranean during deposition of sapropel S1: stalagmite evidence from Corchia cave (Central Italy). Quat Sci Rev 26(3-4):279-286

Zanchetta G, Sulpizio R, Roberts N, Cioni R, Eastwood WJ, Siani G, Caron B, Paterne M, Santacroce R (2011) Tephrostratigraphy, chronology and climatic events of the Mediterranean basin during the Holocene: an overview. Holocene 21(1):33-52

Zanchetta G, Van Welden A, Baneschi I, Drysdale R, Sadori L, Roberts N, Giardini M, Beck C, Pascucci V, Sulpizio R (2012) Multiproxy record for the last 4500 years from Lake Shkodra (Albania/Montenegro). J Quat Sci 27(8):780-789 